Kajian Jurnalisme

ISSN 2549-0559 (cetak) ISSN 2549-1946 (online)

Volume 02 Nomor 01 Tahun 2018

\title{
Efek Komunikasi Massa Program Citizen Report Di Radio PRFM Bandung
}

\author{
Iriyanti Mendayun dan Dian Wardiana Sjuchro \\ Program Studi Jurnalistik, Fakultas Ilmu Komunikasi, Universitas Padjadjaran, \\ E-mail: iryn.mendayun@gmail.com
}

\begin{abstract}
In existence of the Media of Citizen Journalist helps citizen in conveying information and opinion on media. However, it also can make the media as a microphone for its citizens in amplyifing a negative image of an institution. Therefore, researchers wanted to examine the attitudes of PR FM Radio's audiences in contemplate the performance of Traffic Police Officers after they have listened to Citizen Report news program on Radio PR FM Bandung. The research used quantitative method with a total population of 183 people. The result has showed that there was no significant relationship between the quality of Citizen Report news program and PRFM Radio audience attitude in contempling the performance of traffic police officers in Bandung. Whether it is controlled by individual psychological organization or not. This study refers to cognitive dissonance theory, whereas explains, that the individual is consistent with his attitude. This has proved, a to the utmost strong correlation between the individual psychological organization and PR FM Radio audience's attitudes in contemplating the performance of Bandung Traffic Police Officers.
\end{abstract}

Keywords: attitude; individual psychological; cognitive dissonance theory; individual differencess theory; organization news program quality

\begin{abstract}
Abstrak
Hadirnya media jurnalis warga, membantu warga menyampaikan informasi dan pendapatnya. Hanya saja ini akan menjadikan media sebagai corong bagi warga untuk memperburuk citra suatu lembaga. Untuk itu peneliti ingin meneliti sikap khalayak Radio PR FM dalam memandang kinerja Kepolisian Lalu Lintas Kota Bandung setelah mendengarkan program Citizen Report di Radio $P R$ FM. Metode yang digunakan dalam penelitian ini adalah metode kuantitatif dengan jumlah populasi sebanyak 183 orang. Hasil penelitian menunjukkan bahwa tidak terdapat hubungan yang signifikan antara kualitas program program Citizen Report dengan sikap khalayak radio PR FM dalam memandang kinerja Kepolisian Lalu Lintas Kota Bandung. Baik itu tidak atau dengan di kontrol organisasi psikologikal individu. Hasil penelitian ini lebih merujuk pada teori disonansi kognitif yang menjelaskan bahwa individu konsisten dengan sikapnya. Ini terbukti cukup kuatnya hubungan antara organisasi psikologikal individu dengan sikap khalayak radio $P R$ FM dalam memandang kinerja Kepolisian Lalu Lintas Kota Bandung.
\end{abstract}

Kata kunci: individual differencess theory; kualitas program berita; organisasi psikologikal; sikap; teori disonansi kognitif 
99 | Kajian Jurnalisme

ISSN 2549-0559 (cetak) ISSN 2549-1946 (online)

Volume 02 Nomor 01 Tahun 2018

\section{Pendahuluan}

Hadirnya media sosial sebagai medium atau ruang virtual bagi sejumlah pengguna dari seluruh penjuru daerah untuk menyatukan pikiran, memberikan pandangan, melakukan kritik, dan menyampaikan opini. Bahkan dengan adanya ruang virtual ini turut memberikan kesempatan bagi pengguna untuk berdiskusi membahas berbagai isu atau permasalahan dan keabsahan informasi yang disampaikan oleh salah seorang pengguna dalam suatu komunitas virtual. Ini menciptakan ruang yang lebih luas bagi masyarakat untuk menyatukan pikiran dan pandangannya terkait dengan kinerja kepolisian di berbagai daerah di Indonesia.

Konsep ini sejalan dengan pendapat Hermawan bahwa mereka tidak hanya membaca berita, tetapi juga aktif memberikan opini seputar kehidupan yang mereka jalani. Mereka juga dengan gampang menyampaikan pandangan terkait dengan isu-isu aktual yang terjadi. Dengan demikian kehadiran internet dan media sosial ternyata bisa semakin meningkatkan partisipasi masyarakat terkait dengan isu-isu publik (Nugraha, 2012:170).

Hadirnya media sosial memungkinkan pengguna untuk saling bertukar informasi tanpa mengenal batas ruang dan waktu. Ini memungkinkan pengguna untuk berbagi informasi dari berbagi penjuru daerah dalam waktu singkat sehingga membuat jangkauan informasi akan jauh lebih meluas. Dengan ini para pengguna dapat mengadukan masalah atau pengalaman yang ia hadapi berkaitan dengan kinerja polisi di tempat-tempat yang berbeda. Bahkan dengan adanya fasilitas untuk memberikan dan membalas komentar di media sosial, masyarakat bisa berbagi pengalaman yang sama atau bahkan memberikan pendapat.

Adanya media sosial sebagai wadah bagi masyarakat dalam menyebarkan dan menanggapi informasi ini membuat institusi media tidak hanya mendapatkan informasi dari berbagai penjuru daerah tetapi juga dapat melihat reaksi khalayak dan isu apa yang sedang hangat diperbincangkan oleh netizen saat itu. Ini menjadi salah satu tanda bergesernya masyarakat yang dianggap sebagai konsumen pasif menjadi jurnalis warga yang telah menempatkan warga sebagai produsen berita sekaligus narasumber berita. Ini ditegaskan kembali oleh Nasrullah (2013:viii) bahwa, "Di era media siber, khalayak tidak sekadar diberikan ruang untuk berinteraksi di media massa yang melakukan konvergensi teknologi ke internet, namun khalayak mulai bergeser bahkan menjadi pesaing karena khalayak turut terlibat dalam produksi berita dan informasi".

Hanya saja, kredibilitas informasi dari jurnalis warga memang masih menjadi pertanyaan dan pertimbangan besar bagi sejumlah media arus utama. Untuk menggunakan karya jurnalis warga, media arus utama harus mempertaruhkan reputasinya sebagai media massa yang kredibel. Risiko menggunakan berita mereka jauh lebih tinggi apalagi hal-hal yang berkenaan dengan etika jurnalistik. Minimnya pengetahuan dan keahlian jurnalis warga menyebabkan informasi yang disampaikan menjadi simpang siur, menyinggung Suku Agama Ras dan Antargolongan (SARA), atau bahkan informasi yang disampaikan bisa saja bohong dan subjektif.

Kesalahan yang kerap dilakukan oleh jurnalis warga ini justru melanggar 3 dari 7 dosa besar pers menurut Paul Johnson (Nugraha, 2012:107), seperti penyimpangan informasi yaitu menambahkan atau mengurangi informasi dengan memasukan opini, dramatisasi fakta, dan pembunuhan karakter. "Sering keabsahan berita dari citizen journalism dianggap lemah 
sebagai jurnalisme karena seharusnya pewarta tetap memegang teguh asas praduga tak bersalah dan pemberian inisial (off the record). Tentu ini bisa dimaklumi karena ketidaktahuan mengenai etika-etika dalam jurnalistik, tidak semua orang yang berperan dalam citizen journalism mengerti bagaimana proses sebuah informasi atau isu bisa berubah menjadi sebuah berita dan menjadi layak untuk disampaikan kepada publik (Zaenudin, 2012:111)".

Ini membuat peran media sebagai penjaga gawang (gatekeepers) menjadi sangat penting dalam menyaring, memilah dan memilih informasi yang masuk untuk kemudian dipublikasikan kepada masyarakat luas. Istilah 'gatekeeping' telah secara luas digunakan sebagai metafora untuk menggambarkan proses di mana seleksi dibuat dalam kerja media, terutama keputusan mengenai apakah diperbolehkan atau tidak sebuah laporan berita tertentu melewati 'pintu' media berita ke dalam saluran berita (McQuail, 2011,42-43).

Peran media massa dalam memberikan informasi (to inform), tentu tidak boleh dilakukan secara sembarangan. Sebab media merupakan kerangka acuan bagi khalayak untuk melihat lingkungannya khususnya sebagai perpanjangan indera, mata, atau telinga khalayak dalam mengindera suatu peristiwa atau kebijakan. Seperti yang disampaikan McQuail yaitu, media massa sebagai sumber informasi dan memiliki peranan yang penting bagi kehidupan manusia, terutama dalam pembentukan pikiran serta sudut pandang penikmatnya. Saat ini informasi sangat mudah didapatkan dan sangat cepat informasi itu diterima oleh publik hingga ke belahan dunia. Demikian signifikan dalam kehidupan sehari-hari sehingga mendominasi 'Lingkungan Simbolik kita (McQuail, 1996:254).

Hanya saja, karena fokus program terletak pada laporan warga yang dengan segala kesadaran dan niatannya memang ingin memberikan aduan melalui media sosial seperti grup Facebook, maka objektivitas program berita secara tak langsung berpihak pada netizen. Sebab, suara khalayak suatu institusi media belum tentu mewakili suara masyarakat suatu kota secara keseluruhan. Namun, media baik secara langsung maupun tak langsung menggambar suara laporan warga di media sosial sebagai "suara publik".

"Kebebasan komunikasi publik tidak pernah bisa mutlak, tetapi harus diketahui batasannya yang terkadang dibuat oleh kepentingan pribadi orang lain atau oleh tujuan kolektif masyarakat yang lebih tinggi"(McQuail,2012:214). Ini menjelaskan bahwa penggunaan karya jurnalis warga sadar atau tanpa disadari oleh institusi media ini belum tentu memenuhi indikator kebebasan media.

Selain itu, keberagaman berita yang dibangun pada program Citizen Report ini cenderung minim. Ini terjadi karena terbatas dan minimnya "point of view" atau cara pandang atas suatu realitas dari berbagai sisi, baik itu dari sefi ekonomi, politik, hukum, kriminal, sosial, budaya, maupun dari segi lainnya pada program tersebut. Menurut pandangan pribadi peneliti ini terjadi karena pihak redaksi mengemas berita hanya berdasarkan pada laporan warga saja dan peran gatekeeper terbatas hanya memverifikasi namun tidak untuk memodifikasi atau menggabungkan informasi warga dengan hasil kerja jurnalis profesionalnya.

Peran gatekeeper sebatas menyaring kebenaran informasi ini membuat objektivitas yang dibangun oleh jurnalis warga cenderung rendah. Ini terjadi menurut Nasrullah (2014:71) karena media jurnalisme warga hampir tidak mensyaratkan "profesionalitasnya". Juga, 
101 | Kajian Jurnalisme

ISSN 2549-0559 (cetak) ISSN 2549-1946 (online)

Volume 02 Nomor 01 Tahun 2018

struktur berita yang dibuat oleh jurnalis warga tidak mensyaratkan perlunya kelengkapan unsur-unsur berita dalam $5 \mathrm{~W}+\mathrm{H}$, perlunya keberimbangan dalam menyajikan fakta, dan konfirmasi terhadap sumber yang sedang diberitakan.

Selain itu berita yang dihasilkan jurnalis warga pada dasarnya merupakan hasil kerja individual frame di mana jurnalis warga bisa memasukkan opini pribadinya ke tubuh berita di mana secara tak langsung mencerminkan keberpihakan warga. Ini sesuai dengan apa yang disampaikan oleh Nasrullah bahwa, opini atau pemihakan jurnalis media tradisional tidaklah bisa dimasukkan ke dalam tubuh berita. Berbeda dengan jurnalis warga, setiap warga bebas mengungkapkan ekspresinya, opininya, pendapatnya, bahkan kritik pedasnya yang diselipkan di dalam tubuh berita yang dibuat. Dengan kebebasan mengelola informasi yang ingin dipublikasikan, kebebasan menyelipkan opini ke dalam informasi yang ditulis tidak menutup kemungkinan adanya keberpihakan warga" (Nasrullah,2014).

Minimnya upaya cover both sides dan pencampuran opini dan fakta dalam tubuh berita ini akan menjadi bukti bahwa upaya objektivitas yang dibangun suatu institusi media turut dipertanyakan. Apakah kedekatan Radio PR FM dengan jurnalis warga mampu menciptakan bias sehingga mengaburkan gambaran realitas atau tidak?

Oleh karena itu, peneliti ingin meneliti tingkat kepercayaan, persepsi, evaluasi, apresiasi atau sikap khalayak pada kinerja Kepolisian Lalu Lintas Kota Bandung dalam mengatasi permasalahan lalu lintas di Kota Bandung setelah mendengarkan laporan warga di media massa, di mana informasinya bersumber dari media sosial.

\section{Metode}

Metode penelitian yang digunakan pada penelitian ini adalah metode penelitian kuantitatif eksplanatif. Penelitian ini bertujuan untuk menjelaskan faktor-faktor yang memperkuat atau memperlemah hubungan antara dua variabel ini yaitu kualitas program berita dan sikap khalayak terhadap kepolisian. "Jika masalah yang Anda pilih mengharuskan identifikasi, faktor-faktor yang memengaruhi hasil, fungsi keterlibatan atau pemahaman prediksi hasil, pendekatan kuantitatif menjadi yang terbaik Anda gunakan. Pendekatan ini juga layak diterapkan untuk menguji suatu teori atau hipotesis" (Creswell, dalam Silalahi, 2015:25).

Survei eksplanatori merupakan penelitian yang menjelaskan pertanyaan "Why" terkait dengan alasan terjadinya suatu hal. Juga pertanyaan "to what extent", "how much", "how far", "how significant" cocok untuk penelitian eksplanasi kuantitatif untuk menjelaskan hubungan antar dua atau lebih variabel. Pertanyaan to what extent, how much, how far, how significant meminta penjelasan berdasarkan satu teori. Ini bertujuan menjelaskan alasan terjadinya peristiwa dan untuk membentuk, memperdalam, mengambangkan, atau menguji teori (Neuman,2016:45).

\section{Metode Pengumpulan Data}

Responden pada penelitian ini khalayak Radio $P R F M$ yang aktif berinteraksi dengan pihak redaksi Radio $P R$ FM secara langsung atau tak langsung melalui medium telepon, SMS, dan media sosial. Total populasi yang didapat sebanyak 348 orang. Jumlah sampel yang didapat 
setelah menggunakan teknik sampling sampling acak distratifikasi (stratified random sampling) sebanyak 183 orang. Populasi dibagi menjadi 5 subpopulasi yang berbeda berdasar medium interaksi, pengetahuan dan pengalamannya terkait jurnalistik.

Data didapat dari redaksi Radio PR FM, Komunitas Netizen Photo PR FM, dan teknik social media mining. Zafarani, dkk (2014:16) menyampaikan bahwa social media mining is the process of representing, analyzing, and extracting actionable patterns from social media data. For effective social media mining, we collect information about individuals and entities, measure their interactions, and discover patterns to understand human behavior.

Adapun teknik pengumpulan data dilakukan dengan menyebarkan angket secara online, wawancara melalui telepon, wawancara dengan redaksi Radio $P R F M$, wawancara dengan pihak Kepolisian Lalu Lintas Kota Bandung, dan mencari informasi tambahan melalu studi kepustakaan.

\section{Pengukuran}

Variabel independen: kualitas program Citizen Report. Pada bukunya yang berjudul Mass Communication Theory: an Introduction, McQuail (1994:251) menyebutkan standar penilaian kinerja media berdasarkan beberapa konsepsi mengenai kepentingan publik yaitu terdiri atas kebebasan media, keberagaman berita, objektivitas berita, dan gambaran atau distorsi realitas: bias. Butir-butir pertanyaan pada variabel ini diukur dengan lima skala sikap yaitu sangat setuju, setuju, ragu-ragu, tidak setuju, dan sangat tidak setuju. Pada penelitian ini standar kualitas program merupakan penilaian khalayak terhadap konten yang disiar dengan kriteria berikut.

Kebebasan Media. McQuail (2012) menjelaskan bahwa hukum dan peraturan penjagaan kebebasan cenderung ditransfer dari isi kepada alatnya yaitu pers sendiri. Tak hanya itu kebebasan media mencakup hak-hak untuk menyatakan sesuatu secara bebas (free expression) dan kebebasan dalam membentuk opini (the free formation fo opinion). Untuk itu, McQauil memaparkan beberapa cara untuk mengukur kebebasan media yaitu mempromosikan demokrasi dan melindungi kepentingan pers. Untuk itu alat ukur dari kebebasan media yaitu mempromosikan demokrasi dan menjaga peran jurnalistik.

Keragaman konten merupakan upaya media untuk menyajikan berita yang lengkap dengan menggunakan prinsip keadilan (fairness). Dalam hal ini prinsip keadilan dinilai berdasar pada prinsip keterwakilan secara proporsional atau mencerminkan keragaman kebutuhan atau minat audiens terhadap berita (McQuail dalam Morissan,2010:63). Untuk itu, terdapat dua subprinsip untuk mengukur keanekaragaman menurut McQuail dan Van Cuilenburg (dalam McQuail,1989:128) yaitu keanekaragaman refleksif dan akses yang terbuka (open access)

Objektivitas adalah bentuk tertentu dari praktik mediadan juga meruapakan sikap tertentu dari tugas pengumpulan, pengelola, dan penyebaran informasi. Ciri utamanya adalah keterlepasan dan netralitas terhadap objek liputan, tidak berpihak atau bias, keterikatan terhadap akurasi dan jenis kebenaran media yang lain (relevansi dan keutuhan), tidak mencampurkan subjektivitas ke dalam realitas yang dilaporkan (McQauil,2012:222). Ciri ini 
sesuai dengan kerangka objektivitas dalam konteks penelitian menurut Westerstahl sebagai berikut:

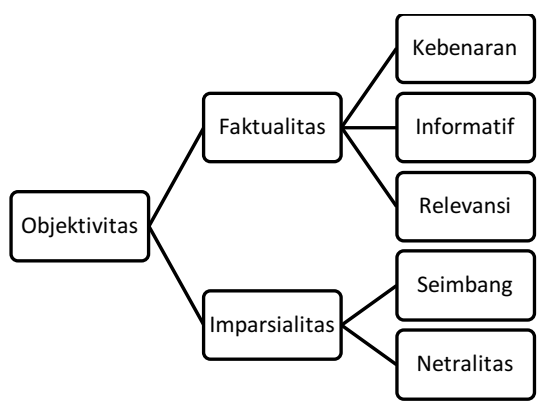

Diagram 1 Komponen Kriterian Objektivitas Westerstahl (Sumber: McQuail,2012:224)

Cerminan atau distorsi realitas: pertanyaan mengenai bias. Bias dalam konten berita dapat merujuk, terutama pada realitas yang distorsi, memberikan gambaran negatif terhadap kelompok-kelompok minoritas, mengabaikan atau salah menanggapi peran wanita dalam masyarakat, atau secara berbeda-beda mendukung partai politik atau filsafat tertentu (Shoemaker dan Resse dalam McQuail,2011:99). Berdasarkan pengertian bias di atas, bias dapat dikenali dalam tiga tipe bias yaitu bias distorsi, bias konten, dan bias dalam mengambil keputusan (Entman dalam Boudana,2016:602).

\section{Variabel dependen: sikap khalayak Radio $P R$ FM terhadap kinerja Kepolisian Lalu Lintas.}

Makna sikap menurut Secord dan Backmann berorientasi pada skema triadik (triadic schema). Menurut pemikiran ini suatu sikap sebagai keteraturan tertentu dalam hal perasaan (afeksi), pemikiran (kognisi), dan predisposisi tindakan (konasi) seseorang terhadap suatu objek (dalam Azwar, 2005:15). Butir-butir pertanyaan pada variabel ini diukur dengan lima skala sikap yaitu sangat setuju, setuju, ragu-ragu, tidak setuju, dan sangat tidak setuju.

Kognisi. Komponen kognisi merupakan representasi apa yang dipercayai oleh individu pemilik sikap mengenai apa yang berlaku atau apa yang benar bagi objek sikap. Kepercayaan datang dari apa yang telah kita lihat atau apa yang telah kita ketahui. Berdasarkan apa yang telah kita lihat itu kemudian terbentuk suatu ide atau gagasan mengenai sifat atau karakteristik umum suatu objek. Sekali kepercayaan terbentuk, maka ia akan menjadi dasar pengetahuan seseorang mengenai apa yang dapat diharapkan dari objek tertentu dan menjadi kecenderungan kita untuk menggeneralisasikannya. Hal inilah yang menjadi cikal bakal stereotip pada objek yang memiliki karakteristik yang kita nilai sama. Seperti yang disampaikan Mann (dalam Azwar,2012:24), komponen kognitif terdiri atas persepsi, kepercayaan, dan stereotip.

Afeksi. Komponen afeksi (Azwar,2012:26-27) menyangkut masalah emosional subjektif seseorang terhadap suatu objek sikap. Secara umum, komponen ini disamakan dengan perasaan yang dimiliki terhadap sesuatu. Pada umumnya reaksi emosional yang merupakan komponen afeksi ini banyak dipengaruhi oleh kepercayaan atau apa yang kita percaya sebagai benar dan berlaku bagi objek yang dimaksud. Afeksi komunikasi yang telah menerima 
informasi dan telah mengakumulasikannya berupa rasa suka komunikan dan juga kepuasan komunikan(Azwar,2005:26).

Konasi. Komponen konasi merupakan kecenderungan perilaku yang ada dalam diri seseorang terhadap objek sikap yang dihadapinya berupa kecenderungan untuk bertindak atau bereaksi dengan cara-cara tertentu. Kecenderungan perilaku banyak dipengaruhi oleh kepercayaan dan perasaan serta konsistensi akan berjalan selaras dengan keduanya. Konasi komunikasi yang telah menerima informasi dan telah mengakumulasinya. Indikatornya menurut Azwar (2005:27) yaitu kecenderungan untuk mendukung dan kecenderuungan berbagi pengalaman.

Variabel kontrol: organisasi psikologikal individu. Berdasarkan pendapat DeFleur (1970:121) dan Effendy (2003:316) di atas dapat didefinisikan bahwa organisasi psikologikal individu merupakan seperangkat nilai, sikap, dan kepercayaan dalam diri manusia yang digunakan untuk mempelajari dan menginterpretasikan lingkungannya. Adapun, kondisi kepribadian dan kondisi fisik khalayak yang terdiri dari pengetahuan khalayak mengenai pokok persoalan, kemampuan khalayak untuk menerima pesan-pesan melalui media yang digunakan, pengetahuan khalayak terhadap perbendaharaan kata yang digunakan (Marhaeni Fajar, 2009:184) juga menjadi bagian dari variabel ini. Ini menjadi alat ukur untuk menjelaskan jumlah khalayak yang memiliki kesamaan rujukan (frame of reference) atau bidang pengalaman (field of experience) baik itu berdasarkan pengalaman masa lalu, rujukan nilai dan norma, pengetahuan, persepsi, pola pikir, atau perasaan mereka dalam menilai kualitas program PR FM dan kinerja Kepolisian Lalu Lintas Kota Bandung.

Sikap dalam pandangan Petty dan Cacioppo menekankan bahwa sikap adalah evaluasi umum yang dibuat manusia terhadap dirinya sendiri, orang lain, objek, atau isu-isu (dalam Azwar,2012). Nilai dan kepercayaan. Nilai merupakan komponen evaluatif dari kepercayaan kita, mencakup: kegunaan, kebaikan, estetika, dan kepuasan. Jadi nilai bersifat normatif, memberi tahu suatu anggota budaya mengenai apa yang baik dan buruk, benar dan salah, siapa yang harus dibela, apa yang harus diperjuangkan, apa yang mesti kita takuti, dan sebagainya. Sementara itu, kepercayaan merupakan anggapan subjektif bahwa suatu objek atau peristiwa punya ciri atau nilai tertentu, dengan atau tanpa bukti (Mulyana,2010:215).

Dalam pengukurannya, nilai dan kepercayaan dijadikan satu indikator karena menurut Rokeach (dalam Debats dan Bartelds,1992:50) salah satu pencetus indikator orientasi nilai individu yang Rokeach Value Survey (RVS) bahwa survei nilai yang dibuatnya dapat mengukur sistem kepercayaan atau orientasi nilai. Dengan kata lain, secara tidak langsung Rokeach menyampaikan bahwa sistem kepercayaan atau orientasi nilai adalah satu kesatuan.

Seperti yang disampaikan oleh Rokeach mendefinisikan bahwa, "Value concept as an enduring belief that a specific mode of conduct or end-state of existence is personally or socially preferable to an opposite or converse mode of conduct or end-state of existence" (dalam Debats dan Bartelds,1992:48). Ini juga didukung oleh pernyataan J.L. Usó-Doménech and J. Nescolarde-Selva (2016:149) bahwa salah satu elemen dari sistem kepercayaan adalah nilai (value). 
105 | Kajian Jurnalisme

ISSN 2549-0559 (cetak) ISSN 2549-1946 (online)

Volume 02 Nomor 01 Tahun 2018

Pengetahuan dan pengalaman individu. Kondisi kepribadian dan kondisi fisik khalayak yang terdiri dari pengetahuan khalayak mengenai pokok persoalan, kemampuan khalayak untuk menerima pesan-pesan melalui media yang digunakan, pengetahuan khalayak terhadap perbendaharaan kata yang digunakan.

\section{Teknik Analisis}

Untuk mengetahui adakah hubungan kualitas program Citizen Report dengan sikap khalayak Radio PR FM, peneliti menggunakan korelasi sederhana dengan Pearson Product Moment (PPM). Selain itu peneliti juga menggunakan korelasi parsial dengan rumus korelasi Perason Product Moment (Product Moment Co-efficient Correlation) untuk mengukur hubungan multivariat dengan organisasi psikologikal individu sebagai variabel kontrol.

Individual Differences Theory melihat individu-individu sebagai anggota khalayak sasaran media massa secara selektif, menaruh perhatian kepada pesan-pesan - terutama jika berkaitan dengan kepentingannya - konsisten dengan sikap-sikapnya, sesuai dengan kepercayaannya yang didukung oleh nilai-nilainya. Adapun anggapan dasar dari teori ini, manusia amat bervariasi dalam organisasi psikologisnya secara pribadi. Variasi ini sebagian dimulai dari dukungan perbedaan secara biologis, tetapi ini dikarenakan pengetahuan secara individual yang berbeda (Effendy,2003:275).

Maka dari itu, signifikansi teoretis dari penelitian ini yaitu peneliti ingin meninjau seberapa kuat hubungan kualitas program Citizen Report dengan sikap khalayak dalam memandang cara kerja kepolisian mengatasi permasalahan lalu lintas? Apakah kekuatan hubungan ini hanya berdasarkan pada keberagaman individu seperti pengetahuan dan pengalaman individu yang berbeda ataukah ada faktor lainnya yang justru memperlemah hubungan ini? Seperti kuatnya pengaruh Radio $P R$ FM karena adanya kedekatan secara personal antara sebagian besar anggota Radio $P R F M$ atau faktor ikut-ikutan karena lingkungan sosialnya cenderung berpihak atau tidak berpihak pada aparat kepolisian. Untuk itu, diharapkan pada penelitian ini dapat menjelaskan faktor apa saja yang membuat seseorang untuk memilih percaya dengan suatu pemberitaan, khususnya yang sumber informasinya berasal dari pengguna media sosial seperti faktor psikologis atau faktor sosialnya.

Menurut Shomaker dan Reese (Fortunato, 2006:3) konten adalah, "The complete quantitative and qualitative range of verbal and visual information distributed by the mass media. "Adapun konten media yang ingin diteliti yaitu program berita sehingga konten media diturunkan menjadi Variabel $\mathrm{X}$ yaitu kualitas program berita.

Kualitas program berita menurut McQuail (2012:212) merupakan standar dan kriteria kualitas yang diaplikasikan terhadap operasi media massa untuk melayani kepentingan publik. Di mana pada pengaplikasiannya institusi media menerapkan nilai normatif seperti kebebasan, kesetaraan, keberagaman, kebenaran, kualitas informasi, serta tatanan sosial dan solidaritas pada tingkat kinerja. Kinerja (performance) merujuk pada konten: apa yang sebenarnya disiarkan kepada khalayak. 
Standard kinerja media McQuail ini disusun merujuk pada kriteria normatif di mana standard ini dibentuk berdasarkan peran pers dalam memenuhi kepentingan publik. Asumsi dasar dari tradisi kajian adalah meskipun kualitas tidak dapat diukur secara langsung, banyak dimensi relevan yang diukur secara reliabel (Boggart dalam McQuail,2011:94).

DeFelur (1970) menyampaikan bahwa manusia memiliki organisasi psikologikal personal atau bisa disebut juga kepribadian berorientasi psikologis khalayak (psychologically oriented personality variables of audience member) yang berbeda-beda. Ini terjadi karena perbedaan setiap individu dalam 'mempelajari' lingkungannya. Proses belajar ini dilihat dari bagaimana mereka memilih stimulus dan menginterpretasikannya dalam cara yang berbeda. Ini dipengaruhi sikap, nilai, kepercayaan, pengetahuan dan pengalaman individu tersebut atau biasa disebut dengan the principle of selective attention and selective perception.

"Human beings raised under widely differing circumstances were exposed to widely differing point of view. From these learning environments they acquired a set of attitudes, values, and beliefs that constituted their personal psychological make-up and set each somewhat apart from his fellows. Individuals values, beliefs, and attitudes played and influential role in determining how he selected stimuli from environment and the way they attributed meaning to those stimuli within his acquired frame of reference once they came to his attention" (DeFleur,1970:121).

Lebih lanjut Effendy (2003:316) menjelaskan individual differences theory menekankan bahwa khalayak yang secara selektif memperhatikan suatu pesan komunikasi, khususnya jika berkaitan dengan kepentingannya, akan sesuai dengan sikapnya, kepercayaannya, dan nilai-nilainya. Tanggapan pesan terhadap pesan komunikasi itu akan diubah oleh tatanan psikologisnya.

Cara khalayak dalam merespons informasi diturunkan menjadi Variabel Y yaitu sikap khalayak. Ini sesuai dengan pernyataan DeFleur (dalam McQuail,1989:234-235) bahwa dalam menilai reaksi khalayak terhadap pengaruh media harus diperhitungkan perbedaan individu, karena sekalipun reaksi yang diharapkan telah terlihat, bukti reaksi itu berbeda-beda sesuai dengan perbedaan kepribadian, sikap, kecerdasan, minat, dan sebagainya. Dalam hal ini peneliti ingin melihat reaksi khalayak berdasarkan sikap yang ia miliki dalam merespons pesan media.

Sikap menurut Azwar (2005:15) bahwa sikap dikatakan sebagai suatu respons yang evaluatif. Respons akan timbul apabila individu dihadapkan pada suatu stimulus yang menghendaki adanya reaksi individual. Respons evaluatif berarti bahwa bentuk reaksi yang dinyatakan sebagai sikap itu timbulnya didasari oleh proses evaluasi dalam diri individu yang memberi kesimpulan terhadap stimulasi dalam bentuk nilai baik-buruk, positif-negatif, menyenangkan-tidak menyenangkan, yang kemudian mengkristal sebagai potensi reaksi terhadap objek sikap. Ini menjelaskan bahwa terbentuknya sikap itu sendiri tidak lepas dari pembelajaran yang dilakukan oleh seseorang yakni melalui pengamatan, pengalaman, dan kesimpulan yang dibuat terhadap suatu objek sehingga akan dapat terbentuk sikap.

Penelitian ini berpendapat bahwa media mampu membentuk dan mengubah sikap khalayak Radio PR FM dalam menilai kinerja Kepolisian Lalu Lintas di Kota Bandung. Hanya 
saja dengan dikontrol variabel organisasi psikologikal individu membuat hubungan antara kualitas program dengan sikap khalayak menjadi melemah. Ini terjadi karena setiap orang memegang dan memiliki nilai, kepercayaan, sikap awal, pengetahuan, dan pengalam yang berbeda. Di mana berdasarkan teori disonansi kognitif bahwa manusia memegang teguh sikap, nilai, dan kepercayaannya. Berdasarkan pada telaah literatur dan kerangka teori, penelitian ini berpendapat bahwa kualitas program memberikan efek pada pembentukan dan perubahan sikap khalayak. Namun efek itu akan melemah apabila khalayak memiliki organisasi psikologikal yang kuat.

Berdasarkan alasan teoretis, penelitian ini bertujuan untuk menelaah tiga pertanyaan penelitian mengenai, efek komunikasi massa program Citizen Report : hubungan kualitas program Citizen Report dengan sikap khalayak Radio PR FM memandang kinerja Kepolisian Lalu Lintas Kota Bandung.

1. Adakah Hubungan Kualitas Program Citizen Report dengan Sikap Khalayak Radio PR FM dalam Memandang Kinerja Kepolisian Lalu Lintas Kota Bandung Menghadapi Permasalahan Lalu Lintas di Kota Bandung?

2. Adakah hubungan kualitas program Citizen Report dengan sikap khalayak $P R F M$ dalam memandang kinerja Kepolisian Lalu Lintas Kota Bandung menghadapi permasalahan lalu lintas di Kota Bandung apabila dikontrol organisasi psikologikal individu?

3. Adakah hubungan organisasi psikologikal individu dengan sikap khalayak $P R F M$ dalam memandang kinerja Kepolisian Kota Bandung menghadapi permasalahan lalu lintas di Kota Bandung?

\section{Hasil Dan Pembahasan}

Tabel 1 Hasil perhitungan uji analisis inferensial dengan Pearson Product Moment

\begin{tabular}{|c|c|c|c|c|c|c|}
\hline Variabel & $\mathbf{r}$ & t hitung & t tabel & Keputusan & Keterangan & $\begin{array}{c}\text { KD } \\
\mathbf{( \% )}\end{array}$ \\
\hline $\mathrm{X}$ dan Y & $-0,029$ & $-0,387$ & $-1,973$ & Ho diterima & $\begin{array}{c}\text { Tidak } \\
\text { Signifikan }\end{array}$ & 0,1 \\
\hline $\mathrm{X}, \mathrm{Y}$ dan Z & $-0,058$ & $-0,782$ & $-1,973$ & Ho diterima & $\begin{array}{c}\text { Tidak } \\
\text { Signifikan }\end{array}$ & 0,3 \\
\hline $\mathrm{Z}$ dan $\mathrm{Y}$ & 0,559 & 9,059 & 1,973 & Ho ditolak & Signifikan & 31,25 \\
\hline
\end{tabular}

Adakah Hubungan Kualitas Program Citizen Report dengan Sikap Khalayak Radio PR FM dalam Memandang Kinerja Kepolisian Lalu Lintas Kota Bandung Menghadapi Permasalahan Lalu Lintas di Kota Bandung?

Pada penelitian ini tidak terdapat hubungan signifikan antara kualitas program Ciitzen Report (X) dengan sikap khalayak terhadap kinerja polantas Bandung (Y). Ini terjadi karena responden bukan masyarakat yang mudah terpengaruh oleh media meski ia memberikan 
penilaian positif terhadap media tersebut. Dengan kata lain teori jarum hipodermik yang mengandung anggapan bahwa media massa menimbulkan efek yang kuat, terarah, segera dan langsung (Effendy,2003:84) tidak terbukti pada masalah penelitian ini.

\section{Adakah hubungan kualitas program Citizen Report dengan sikap khalayak $P R$ FM dalam memandang kinerja Kepolisian Lalu Lintas Kota Bandung menghadapi permasalahan lalu lintas di Kota Bandung apabila dikontrol organisasi psikologikal individu?}

Setelah memasukkan organisasi psikologikal sebagai variabel $(Z)$ atau variabel kontrol antara kualitas program Citizen Report (X) terhadap sikap khalayak Radio PR FM (Y) dalam memandang kinerja Kepolisian Lalu Lintas Kota Bandung tetap tidak memiliki hubungan yang signifikan sehingga teori individual differences tidak terbukti pada masalah penelitian ini. Teori yang dicetuskan oleh DeFleur ini menelaah perbedaan-perbedaan individu sebagai sasaran media massa ketika mereka diterpa sehingga menimbulkan efek tertentu.

DeFleur (2016 :136) menyatakan bahwa, "When people process any kind of information, including mass media content, Individual differences in psychological organization and functioning will be determining factors in how the individual responds to that information." DeFleur menyampaikan ketika khalayak ingin merespons pesan media terdapat variabel antara yang membuat respons setiap orang berbeda-beda, "The logical sturcture of the individual differences theory is a "cause-(intervening processes)-effect" stucture, just as was the mechanistic S-R before it"( DeFleur \& Ball-Rokeach,1970:122). Ini menjelaskan pendapat DeFleur bahwa terdapat variabel kontrol bagi individu dalam memberikan respons pesan media.

Variabel kontrol merupakan variabel yang memengaruhi variabel independen atau variabel dependen sehingga dapat mengubah hubungan antara kedua variabel tersebut. Variabel kontrol dapat dibedakan menjadi dua yaitu variabel penekan dan variabel pengganggu. Disebut variabel penekan apabila dalam analisis awal $\mathrm{X}$ dengan $\mathrm{Y}$ tidak tampak ada hubungan antara dua variabel, namun setelah setelah variabel ketiga sebagai variabel kontrol dimasukkan (X-Z-Y) maka hubungan antara dua variabel tersebut menjadi tampak. hubungan antara dua variabel tersebut menjadi tampak. Sementara variabel pengganggu adalah apabila variabel kontrol yang dimasukkan justru membuat hubungan antara dua variabel X-Y yang sebelumnya tampak menjadi tak tampak (Silalahi,2015:190).

Berdasarkan pada penjabaran di atas dapat diidentifikasikan bahwa tidak terdapat hubungan antara variabel kualitas program Citizen Report di Radio PR FM dengan sikap khalayak terhadap kinerja polantas dengan dan/atau tanpa variabel kontrol, organisasi psikologikal individu. Ini berarti bahwa media massa tidak memiliki peran apapun terhadap pembentukan dan/atau perubahan citra Kepolisian Lalu Lintas Kota Bandung dan sikap khalayak terhadap kinerja Kepolisian Lalu Lintas Kota Bandung.

Adakah hubungan organisasi psikologikal individu dengan sikap khalayak PR FM dalam memandang kinerja Kepolisian Kota Bandung menghadapi permasalahan lalu lintas di Kota Bandung? 
Hubungan antara organisasi psikologikal individu (Z) dengan sikap khalayak. Tak ada satu pun hubungan variabel dan subvariabel kualitas program Citizen Report (X) dengan sikap khalayak Radio PR FM (Y) baik dengan atau tanpa variabel kontrol ini mengindikasikan bahwa organisasi psikologikal inidividu yang terdiri atas nilai dan kepercayaan, sikap awal, pengetahuan dan pengalaman masa lalu terkait kinerja polantas memberikan pengaruh yang lebih kuat dari yang diberikan media kepada responden. Ini terbukti koefisien korelasi organisasi psikologikal individu (Z) dengan sikap khalayak (Y) sebesar 0,559 dengan koefisien determinasi sebesar 31,25\%. Artinya, sikap khalayak Radio PR FM terhadap kinerja Polantas Bandung dipengaruhi oleh organisasi psikologikal individu (Z) sebesar 31,25\%, sedangkan sisanya sebesar $68,75 \%$ dipengaruhi faktor lainnya. Ini terjadi karena manusia merupakan individu pencari konsistensi kognitif. Beberapa teori konsistensi kognitif yaitu teori disonansi kognitif Festinger dan teori keseimbangan Heider.

Leon Festinger (dalam Morissan,2013:67) menyampaikan bahwa dalam teorinya, disonansi kognitif, manusia membawa berbagai macam unsur (elemen) kognitif dalam dirinya. Sepertinya elemen sikap, persepsi, pengetahuan, dan elemen tingkah laku (bahavior). Masingmasing elemen ini tidak terpisah satu sama lain namun saling memengaruhi dalam suatu sistem yang saling berhubungan. Terdapat dua ide penting yang menjadi dasar teori disonansi kognitif yaitu pertama, keadaan disonansi menghasilkan ketegangan atau stres yang memberikan tekanan untuk berubah.

Kedua, jika kondisi disonansi muncul, maka orang akan berupaya untuk tidak hanya menguranginya, namun juga berupaya untuk menghindarinya (dalam Morissan,2013:67). Manusia mengupayakan konsistensi dalam beberapa cara - antara sikap, antara perilaku, antara sikap dan perilaku, dalam persepsi kita tentang dunia, dan bahkan dalam perkembangan kepribadian. Apabila terjadi inkonsistensi, manusia berupaya mengeliminasi inkonsistensi bahkan dengan cara-cara yang irasional untuk mencapai pemahaman, untuk membenarkan pengalaman-pengalaman yang menyakitkan, atau membuat dunia sesuai dengan kerangka referensi/rujukan"-nya (Severin \& Tankard,2011:155-156).

Lebih lanjut Heider (dalam Severin \& Tankard,2011:156) menjelaskan bahwa dalam keadaan seimbang atau stabil individu akan menolak pengaruh-pengaruh dari luar. Keadaan tidak seimbang diasumsikan tidak stabil dan menciptakan ketegangan psikologis dalam diri seseorang. Ini sesuai dengan pepatah rakyat, "Don't confuse me with the fact, I have already made up my mind (jangan buat saya bingung dengan fakta, saya sudah mengambil keputusan)." (dalam Severin \& Tankard,2011). Festinger juga mengutarakan pendapat yang sama bahwa karena secara psikologis tidak nyaman, maka akan memotivasi seseorang untuk berusaha mengurangi disonansi dan mencapai harmoni/keselarasan dan selain mereka akan berupaya secara aktif menolak situasi-situasi dan informasi yang sekiranya akan meningkatkan disonansi (Severin \& Tankard,2011:165)

Dengan kata lain dalam kasus responden pada penelitian ini, mereka mencoba untuk mempertahankan konsistensi kognitifnya yaitu dengan mempertahankan nilai \& kepercayaan, sikap, dan pengalaman serta pengetahuan masa lalunya terkait kinerja Kepolisian Lalu Lintas Kota Bandung. Citra Kepolisian Lalu Lintas Kota Bandung tidak serta-merta menjadi membaik di mata responden karena bekerja sama dengan Radio $P R F M$ yang dikenal oleh responden sebagai media yang postif dan menjaga independensinya. Adapun alasan mengapa terpaan 
ISSN 2549-0559 (cetak) ISSN 2549-1946 (online)

Volume 02 Nomor 01 Tahun 2018

media tidak berpengaruh pada responden yaitu responden berupaya mengurangi inkonsistensi dalam dirinya mengenai citra polantas.

Festinger (dalam Morissan,2013:68) membayangkan sejumlah metode yang digunakan manusia untuk mengatasi masalah ketidaksesuaian kognitif seperti:

a. Mengubah salah satu atau elemen kognitif yang ada

b. Menambahkan elemen baru dalam hubungan yang inkonsisten itu

c. Mempertimbangkan kembali bahwa disonansi yang terjadi bukanlah sesuatu yang penting

d. Berupaya mencari informasi tambahan untuk mendukung objek atau perihal yang membuat individu merasa inkonsisten

e. Mengurangi disonansi yang terjadi dengan mendistorsi atau menyalahartikan informasi yang terlibat.

Adapun Festinger (dalam Severin \& Tankard,2011:166) menyebutkan kepatuhan terpaksa, di mana teori disonansi merumuskan bahwa ketika seseorang ditempatkan pada sebuah situasi di mana di harus berperilaku di depan umum yang bertentangan dengan sikap pribadinya. Situasi semacam ini sering terjadi karena sebagai akibat dari janji pemberian penghargaan atau ancaman hukuman, tetapi kadang hanya akibat tekanan kelompok untuk menyesuaikan terhadap sebuah norma yang tidak terlalu disetujuinya.

Pendapat Festinger ini didukung dengan orang-orang yang menganggap keakuran (conformity) sebagai nilai dan kepercayaan yang sangat penting yang yaitu sebanyak $62,3 \%$ dari 183 orang atau sebanyak 114 orang. Ini merupakan jumlah terbanyak bila dibandingkan dengan nilai dan kepecayaan lainnya Orang yang menganggap bahwa keakuran merupakan nilai dan kepercayaan yang sangat penting menurut Schwartz (2006:7) cenderung menahan diri dari tindakan, kecenderungan, dan impuls yang dapat merugikan orang lain dan melanggar harapan sosial atau norma-norma. Orang yang menganut nilai ini mengutamakan kepatuhan, disiplin diri, kesopanan, menghormati orang tua. [Comformity:loyal, bertanggung jawab].

Inilah alasan meningkatnya jumlah responden yang mendukung program polantas meski penilaian terhadap kinerja polantas cenderung menurun setelah mendengarkan Radio $P R$ $F M$ dan jumlah responden yang mengetahui, mengalami atau menyaksikan mereka terkait pelayanan buruk meningkat dari 105 orang $(57,4 \%)$ menjadi 114 orang $(62,3 \%)$ (lihat tabel 4.59 dan 4.61). Responden merasa tetap harus mematuhi peraturan lalu lintas sebagai rasa tanggung jawabnya meski mengalami, mengetahui, atau menyaksikan bahwa Kepolisian Lalu Lintas Kota Bandung memberikan pelayanan buruk. Responden yang menganggap penting nilai ini melakukan kebajikan untuk menghindari dampak negatif bagi dirinya. Seperti kekhawatiran apabila ia tidak mematuhi peraturan dan mendukung program polantas Bandung ia bisa kapan saja dihukum meski kinerja polantas dinilai rendah.

Konsistensi antara kepercayaan sebagai komponen kognitif, perasaan sebagai komponen afektif, dengan tendensi perilaku sebagai komponen konatif seperti itulah yang menjadi landasan dalam usaha penyimpulan sikap yang dicerminkan oleh jawaban terhadap skala sikap. Namun, keliru apabila mengharapkan adanya hubungan sistematis yang langsung antara sikap dengan perilaku nyata dikarenakan sikap tidaklah merupakan determinan satusatunya bagi perilaku (Azwar, 2012:27). 
Azwar menyampaikan bahwa interaksi ketiga komponen sikap ini harus berjalan selaras. Apabila ada salah satu bagian komponen sikap tidak konsisten ini akan menyebabkan timbulnya mekanisme perubahan sikap. Apabila sikap awal kepada kinerja Kepolisian Lalu Lintas Kota Bandung negatif karena memiliki pengalaman buruk dengan Polantas Kota Bandung, setelah ia mendengarkan siaran Radio $P R F M$ ada kemungkinan sikap responden berubah. Ini terjadi karena bisa saja responden mengetahui fakta baru dari siaran Radio $P R F M$ bahwa Polantas Kota Bandung sedang berusaha untuk mengubah citra mereka dengan berbagai program baru dan realisasi yang nyata.

Adapun tidak selamanya inkonsistensi konsistensi komponen sikap ini akan memberikan efek yang berseberangan dari sikap awal. Seperti awalnya bersikap negatif namun setelah diberikan stimulus sikapnya berubah menjadi positif. Azwar menyampaikan bahwa bila seseorang sedari awal bersikap negatif namun suatu ketika terjadi gejolak batin karena ketidakseimbangan komponen sikap dalam dirinya, seseorang bisa bersikap ekstrem dengan bersikap sangat negatif sebagai reaksi pertahanan ego seseorang. Dalam kondisi tertentu reaksi seseorang dan berbeda-beda bergantung dari sebera kompleks komponen afektifnya. "Dalam proporsinya, suatu sikap yang didominasi oleh komponen afektif yang kuat dan kompleks akan lebih sukar untuk berubah walaupun dimasukkan informasi baru yang berlawanan mengenai objek sikapnya" (Azwar,2012:30).

Ini sesuai pada data tabel lihat tabel 4.67 dan tabel 4.68. bahwa jumlah responden yang suka dengan kinerja polantas meningkat tipis namun yang merasa puas menurun cukup drastis. Ini terjadi karena tingginya jumlah prasangka negatif atau stereotip buruk mengenai polantas Bandung. Meski angkanya menurun setelah mendengarkan program Citizen Report di Radio PR FM namun jumlahnya mencapai sebagian besar dari responden. Selain itu pula banyak masyarakat yang merasa ragu-ragu bahwa polantas dapat menghadapi masalah lalu lintas dengan menciptakan program yang efektif untuk mengatasinya. Ini sesuai dengan pendapat Azwar (2012:26-27) bahwa reaksi emosional yang merupakan komponen afektif ini banyak dipengaruhi oleh kepercayaan atau apa yang kita percaya sebagai benar dan berlaku bagi objek yang dimaksud.

Salah satu hambatan komunikasi di mana pesan sosialisasi dari pihak Kepolisian Lalu Lintas Kota Bandung adalah munculnya stereotip bahwa Kepolisian Lalu Lintas Kota Bandung kerap mengambil keuntungan pribadi dengan mengambil pungutan liar, membeda-bedakan perlakuan pada pengguna jalan, melayani pengurusan SIM tembak, dan sebagainya. Inilah yang menyulitkan pihak Kepolisian Lalu Lintas Kota Bandung dalam mengubah citra ke arah yang lebih positif. Rakhmat (2008:224) menyampaikan bahwa citra terbentuk berdasarkan informasi yang kita terima. Media massa bekerja untuk menyampaikan informasi. Buat khalayak, informasi itu dapat membentuk, mempertahankan atau meredefinisikan citra.

Mulyana (2010:237) menyebutkan bahwa stereotip merupakan salah satu alasan yang menyebabkan kekeliruan dan kegagalan persepsi. Menggeneralisasikan orang-orang berdasarkan sedikit informasi dan membentuk asumsi mengenai mereka berdasarkan keanggotaan mereka dalam suatu kelompok. Inilah yang menyebabkan polisi dinilai sebagai lembaga yang korup.

Setelah 2013, hasil survei Transparency International Indonesia (TII) menobatkan Kepolisian Republik Indonesia sebagai lembaga paling korup. Pada 2015 Litbang Kompas 
kembali mengadakan jajak pendapat terkait dengan citra Kepolisian Republik Indonesia. Menurut hasil survei pada gambar 1.1, responden yang menilai citra Polri meningkat dari 24,2 persen pada 2013 menjadi 52,1 persen pada 2015. Hanya saja, peran Polri sebagai institusi penegak hukum masih dinilai minor oleh publik. Enam dari 10 responden mengaku tidak puas terhadap kinerja kepolisian dalam penegakan hukum, sementara hanya sepertiga bagian responden yang mengaku puas (WikiDPR.org,2015).

Pada 2016 citra Polri tak kunjung mengalami perbaikan. Menurut hasil survei dari Center of Strategic and Internal Studies (CSIS) terhadap 3.900 responden di 43 provinsi menyebutkan bahwa kepolisian adalah lembaga negara yang rentan terhadap korupsi (Sidik, bisnis.com,2016). Lebih lanjut, Ketua Komisi III DPR Desmon J. Mahesa bahwa setidaknya ada dua hal yang membuat citra lembaga kepolisian buruk yaitu Reserse kriminal (Reskrim) dan Polisi Lalu Lintas (Polantas)(RMOL,2015).

Tindakan memberikan stereotip yang kerap dilakukan responden ini cenderung menggeneralisasikan setiap orang yang menjadi bagian dari polisi lalu lintas sebagai orang yang korup. Lebih lanjut Mulyana menjelaskan (2010:239) bahwa: pertama, sebagai manusia kita cenderung membagi dunia ke dalam dua kategori: kita dan mereka. Lebih jauh, orangorang yang kita persepsi sebagai di luar kelompok kita dipandang sebagai lebih mirip satu sama lain daripada orang-orang dalam kelompok kita sendiri. Dengan kata lain, karena kita kekurangan informasi mengenai mereka, kita cenderung menyamaratakan mereka semua, dan menganggap mereka sebagai homogen.

Kedua, stereotip tampaknya bersumber dari kecenderungan kita untuk melakukan kerja kognitif sesedikit mungkin, dalam berpikir mengenai orang lain. Dengan memasukkan orang ke dalam kelompok, kita dapat mengasumsikan bahwa kita mengetahui banyak tentang mereka (sifat-sifat utama mereka, bagaimana kecenderungan perilaku mereka), dan kita menghemat tugas kita yang menjemukan untuk memahami mereka sebagai individu. Pada umumnya, stereotip bersifat negatif. Inilah salah satu alasan yang cukup kuat mengapa sikap responden sulit berubah, yaitu karena untuk menilai kinerja Kepolisian Lalu Lintas Kota Bandung akan lebih mudah menilai mereka secara homogen daripada membedakan mereka secara individu.

Selain alasan yang dipaparkan di atas, alasan teori konsistensi kognitif terbukti pada penelitian ini yaitu menurut salah satu konsep aktivitas Jay G. Blumler (dalam Baran dan Davis,2010:297) bahwa khalayak kebal terhadap pengaruh. Khalayak sering kali keras kepala, mereka tidak ingin dikontrol oleh siapa pun atau apa pun, bahkan media massa. Khalayak secara aktif menghindari pengaruh dari media. Sementara itu Biocca mengartikan sebagai mengikuti alur konsep 'khalayak yang keras kepala, konsep aktivitas di sini menekankan batasan yang diatur anggota khalayak untuk tidak menginginkan adanya pengaruh atau pembelajaran. Pembaca, penonton, atau pendengar tetap memegang kendali dan tidak terpengaruh kecuali sebagaimana yang ditentukan oleh pilihan pribadi (McQuail,2011:164).

Itulah beberapa alasan yang menyebabkan pesan media massa tidak memiliki pengaruh yang cukup kuat dalam memberikan pembentukan dan/perubahan sikap khalayak pada masalah penelitian ini baik dengan atau tanpa variabel kontrol yaitu organisasi psikologikal individu.

\section{Simpulan}


Berdasarkan hasil penelitian mengenai "Hubungan Kualitas Program Citizen Report dengan Sikap Khalayak Radio PR FM dalam Memandang Kinerja Kepolisian Lalu Lintas Kota Bandung Menghadapi Permasalahan Lalu Lintas di Kota Bandung" dapat ditarik kesimpulan sebagai berikut: (1). Tidak terdapat hubungan antara kualitas program Citizen Report (X) dengan sikap khalayak Radio $P R F M(\mathrm{Y})$ dalam memandang kinerja polantas Bandung menghadapi masalah lalu lintas di Kota Bandung. Dengan kata lain, sikap khalayak Radio $P R$ $F M$ dalam memandang kinerja polantas Bandung tidak dipengaruhi oleh akumulasi dari karakteristik kualitas program Citizen Report seperti kebebasan media, keberagaman berita, objektivitas berita, dan gambaran/distorsi : bias. (2). Tidak terdapat hubungan antara kualitas program Citizen Report (X) yang terdiri atas kebebasan media (X1), keberagaman berita (X2), objektivitas berita (X3), dan gambaran atau distorsi realitas: bias (X4) dengan sikap khalayak Radio PR FM(Y) dalam memandang kinerja polantas Bandung menghadapi masalah lalu lintas di Kota Bandung bila dikontrol dengan organisasi psikologikal individu (Z). Organisasi psikologikal individu seperti kesamaan sikap awal, kerpecayaan dan nilai, serta pengetahuan dan pengalaman tidak memberikan peran apapun dalam memperkuat atau hubungan kualitas program Citizen Report dengan sikap khalayak Radio PR FM. (3).Terdapat hubungan yang cukup kuat antara organisasi psikologikal individu (Z) dengan sikap khalayak Radio $P R F M$ dalam memandang kinerja polantas Bandung menghadapi masalah lalu lintas di Kota Bandung (Y) ini mengindikasikan bahwa teori individual differencess DeFleur tidak terbukti pada penelitian ini. Penelitian ini lebih merujuk pada teori konsistensi seperti disonansi kognitif Leon Festinger. Bahwa individu cenderung mempertahankan konsistensi kognitif dalam dirinya dan mengabaikan pesan media yang tidak sesuai dengan dirinya.

\section{Daftar Pustaka}

Azwar, Saifuddin. (2005). Sikap Manusia: Teori dan Pengukurannya. Yogyakarta:Pustaka Pelajar. Azwar, Saifuddin. (2012). Sikap Manusia: Teori dan Pengukurannya. Yogyakarta:Pustaka Pelajar.

Baran, Stanley J. dan Dennis K. Davis. (2010). Teori Komunikasi Massa: Dasar, Pergolakan, dan Masa Depan. Jakarta: Salemba Humanika.

Boudana,Sandrine. (2016). "Impartiality is not fair: Toward an alternative approach to the evaluation of content bias in news stories." Diakses dari http://jou.sagepub.com/content/17/5/600.full.pdf

DeFleur, Melvin L dan Sandra Ball-Rokeach. (1970). Theories of Mass Communication. New York: McKay

DeFleur, Melvin L.dan Margaret H. DeFleur. (2016). Mass Communication Theories: Explaining Origins, Processes, and Effects.New York : Routledge

Debats, D.L. \& Bartelds, B.F. (1996). "The structure of human values: a principal components analysis of the Rokeach Value Survey (RVS)”. Disertasi Doktoral Universitas Groningen. Diakses dari www.rug.nl/research/portal/files/10223324/c5.pdf

Effendy, Onong Uchjana. (2003). Ilmu, Teori, \& Filsafat Komunikasi. Bandung : Citra Aditya Bakti Bandung.

Erianto, Dwi. (2015). “(Litbang Kompas) Dua Wajah Kepolisian”. http://wikidpr.org/news/litbangkompas-dua-wajah-kepolisian. Diakses pada 11 Juni 2016 pukul 23.35 WIB

Fajar, Marhaeni. (2009). Ilmu Komunikasi Teori \& Praktek Edisi Pertama.Yogyakarta: Graha Ilmu.

Fortunato, John A. (2006). Making Media Content: The Influence of Constituency Groups on Mass Media. London :Routledge. 
ISSN 2549-0559 (cetak) ISSN 2549-1946 (online)

Volume 02 Nomor 01 Tahun 2018

McQuail, Denis. (1989). Teori Komunikasi Massa: Suatu Pengantar. Diterjemahkan oleh Agus Dharma dan Aminuddin Ram. Jakarta: Erlangga.

McQuail,Denis. (1994). Mass Communication Theory:an Introduction. Londong: Sage Publications Ltd.

McQuail, Denis. (1996). Teori Komunikasi Massa Suatu Pengantar. Jakarta: Erlangga

McQuail, Denis. (2012). Teori Komunikasi Massa McQuail Buku 1.Jakarta: Salemba Humanika.

McQuail, Denis. (2011). Teori Komunikasi Massa McQuail Buku 2.Jakarta: Salemba Humanika.

Morissan, Andy Corry Wardhani, dan Farid Hamid. (2010). Teori Komunikasi Massa.Bogor: Ghalia Indonesia.

Morissan. (2013). Teori Komunikasi: Komunikator, Pesan, Percakapan, dan Hubungan (Interpersonal), Bogor: Ghalia Indonesia.

Mulayana, Deddy. (2010). Ilmu Komunikasi : Suatu Pengantar. Bandung: PT Remaja Rosdakarya.

Nasrullah, Rulli. (2013). Cyber Media.Yogyakarta:CV Idea Sejahtera

Nasrullah,Rulli. (2014).Teori dan Riset Media Siber :(Cybermedia). Jakarta: Kencana Prenada Media Group.

Neuman, W. Lawrence. (2016). Metodologi Penelitian Sosial: Pendekatan Kualitatif dan Kuantitatif. Diterjemahkan oleh Edina T. Sofia. Jakarta: PT Indeks.

Nugraha, Pepih. (2012). Citizen Journalism Pandangan, Pemahaman, dan Pengalaman. Jakarta: Penerbit Buku Kompas.

Rakhmat, Jalaluddin. (2008). Psikologi Komunikasi. Bandung: PT Remaja Rosdakarya.

Schwartz, Shalom H. (2006). Basic Human Values: Theory, Measurement, and Applications. Universitas Hebrew Jerusalem. Diakses dari https://www.researchgate.net/file.PostFileLoader.html?id=54ef46b6d3df3e92378b4599\&asset Key=AS\%3A273722051629058\%401442271830410.

Severin, Werner J. \& James W. Tankard, Jr. (2011). Teori Komunikasi Sejarah, Metode dan Terapan di dalam Media Massa edisi kelima, Jakarta:Kencana Prenada Media Group.

Sidik, Fajar.2016. Survei: Citra Kepolisian Kebalikan Dari KPK. http://bandung. bisnis.com/read/20160727/34239/558617/survei-citra-kepolisian-kebalikan-dari-kpk. Diakses pada pada 12 September 2016 pukul 14:33 WIB.

Silalahi, Ulber. (2015). Metode Penelitian Sosial Kuantitatif. Bandung : PT Refika Aditama.

Usó-Doménech, J. L. dan J. Nescolarde-Selva. (2016). “What are belief systems?” Jurusan Matematika Terapan. Universitas Alicante. Alicante. Spanyol. Diakses dari www.vub.ac.be/CLEA/FOS/cfp/what-are-belief-systems.pdf

Vebriyanto, Widian. (2015). "Desmon: Reskrim dan Polantas Perusak Citra Polisi". http://www.rmol.co/read/2015/06/04/205022/Desmon:-Reskrim-dan-Polantas-Perusak-CitraPolisi-. Dikases pada 11 Juni 2016 pukul 16.23 WIB.

Zaenudin, Heni Nuraeni. (2012). Digitalisasi dan Konvergensi Media Vol.10 Nomor 2. Bandung :BPPKI.

Zafarani, Reza, Mohammad Ali Abbasi, dan Huan Liu. (2014). Social Media Mining: an Introduction. Cambridge University Press. Diakses dari ttp://dmml.asu.edu/smm pada 14 April 2017 pukul 22.23 WIB. 